\title{
NATIONS, IDENTITIES AND GLOBAL TECHNOLOGIES
}

\author{
Mark Poster \\ Unıversıty of Calıfornia, Irvıne \\ U.S.A.
}

\begin{abstract}
As a political unit, the nation is facing an ever-expanding set of challenges. Modern systems of transportation and communication facilitate global exchanges of commodities, populations and information, often evading the borders and jurisdictions of the nation state. Faced with an increasingly interconnected globe, the nation may no longer be able to sustain its territorial hegemony. Nor may it be able to contain citizens within national identities. This talk examines the role of the Internet in these processes.

I examine how the Internet affects two features of the nation: sovereign borders and national identity. I contrast the role of print in the formation of national identity with that of communication in cyberspace. I surmise that in addition to a global economy, we may be seeing the emergence of a global culture with severely diminished prominence of the nation. I raise the question of a new global political unit and its possible relations to older forms of political community. Is the Internet a vehicle of U.S. domination or the basis of new political forms that combine the global and the local in new, possibly less hierarchical ways than in the past? What are the possibilities and challenges to the flow of information in this context?
\end{abstract}

Keywords: National identity, nation state, Internet, globalization, culture.

\section{About the Author}

Mark Poster is Professor of History and Director of the Critical Theory Institute at the University of California, Irvine. His most recent books are The Information Subject (1999), Cultural History and Postmodernity (1997), The Second Media Age (1995), and The Mode of Information (1990). 